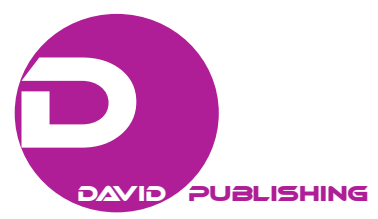

\title{
The 2015 Migratory Crisis: The Disillusion of Visiting Rights
}

\author{
Nader Vahabi \\ CADIS EHESS, (School of Advanced Studies in Social Sciences) \\ University of Toulouse (LISST), France
}

\begin{abstract}
What has really happened in Europe since 2014? Why in 2018 are so many migrants still making their way towards Europe? For the first time since the Second World War, an important number of individuals have entered into European soil. The idea for this article goes back to October 2015 when the prefet from the town where I live went in search of asylum seekers. This is what sparked off my inquiry amongst about 50 exiles housed in the annex of the Montmorency (95) hospital in July 2015. But against popular belief, migrants are not accepted fairly into countries, and the geographical distribution of Syrians in Turkey, Lebanon, Jordan, and Europe is contrary to what Kant had defended as a "right to visit". Although the majority of researchers suggest welcoming migrants, it is necessary to reconsider some methodological and epistemological aspects and get away from some wrongly perceived concepts which dated prior to the year 2000. Yet, the Arab Spring has showed that we are dealing with unfinished post-colonialism, something that we will soon come back to in another article where we will propose another solution.
\end{abstract}

Keywords: migratory crisis, visiting rights, Kant, trajectory, post-colonialism

\section{Introduction}

What has really happened in Europe since 2014? Why have so many migrants made their way towards Europe? According to the High Commission for Refugees, the old continent welcomed in 2012, 2013, and 2014 respectively: 355500, 435190, and 525,000 asylum seekers and in 2015, 1,046,599 (out of which 1,011,712 arrived by sea and 34,887 overland). When we study the origin of these migratory fluxes we can notice that in 2015, $80 \%$ of them came from three countries: Syria 520,000 (50.2\%), Iraq 200,000 (20.02\%), Afghanistan $70,000(7.1 \%)^{1}$.

We noted the reproduction of migration two years later in 2016. You can see this in the graph below (see Figure 1).

Nader Vahabi, Ph.D. in Social Politics, Associate Researcher in Sociology at School of Advanced Studies in Social Sciences (CADIS) in Paris and University of Toulouse I1 (Rural Dynamics).

${ }^{1}$ http://www.unhcr.org/fr/apercu-statistique.html, consulted September 10th 2016. 


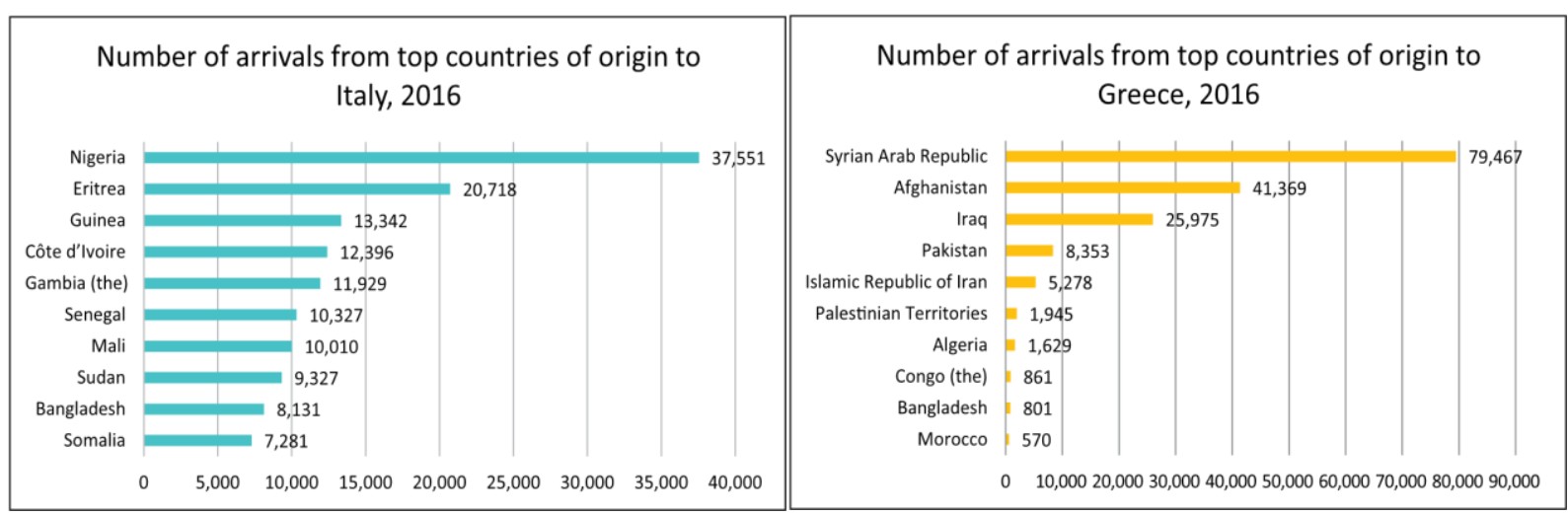

Figure 1. Top 10 countries and territories of origin — arrivals in Italy and Greece, $2016^{2}$.

By comparing these two graphs from 2016, we can see that the profile-type of asylum seekers changes according to the journey undertaken in the eastern or central Mediterranean. As well as that, as long as the conflict continues in a zone (civil war in Iraq, in Syria, Afghanistan and conflict in Africa), the migratory flux does not subside.

For the first time since the Second World War, an important number of individuals have entered into European soil. The development of the migratory flux and the increase in the number of refugees are partly consistent with the civil wars in the three countries mentioned.

Without doubt the opportunities proposed by European countries attracted individuals in the choice of their destination (Vahabi, 2012, p. 65). The unemployment rate, the right to work, social help, the right to housing, and cultural rapprochement (language, religion) are important criteria in attracting them.

Germany, with an unemployment rate of 5.2\%, the lowest for 10 years, a very flexible market, the perspective of finding a job, even an unqualified lowly paid one, its negative demographic imbalance as scientifics have quoted, and especially the chancellor Angela Merkel's strength and determination, has become the top destination for migrants.

England has certain advantages and is in second place amongst the astray.

France, with more than $10 \%$ unemployment and a housing problem, does not appeal.

However, certain prefects (in Val d'Oise for example), have shown initiative by going to Germany and bringing back a limited number of asylum seekers. This is what sparked off my inquiry amongst about 50 migrants housed in the annex of the Montmorency (95) hospital in July 2015.

\section{The Different Trajectories}

Our inquiry shows how the different trajectories are constructed according to individuals' resources, the constraint of exile, personal ability to manage themselves, and political relations between the exile's country and the host states. Before departure, the migrant conceives an overall plan of itineraries and the means he deposes of in order to arrive at destination; he possesses what we can call a trajectory schema (Strauss, 1992) which cannot be devised to the last detail (it is rarely probable, but it implies an imaged representation of the envisaged succession of events and the actions to foresee). The forms of trajectory therefore turn out to be very dissimilar from each other.

\footnotetext{
2 IOM's Global Migration Data Analysis Centre (GMDAC) (2017). Migrant deaths and disappearances worldwide: 2016 analysis, ISSN 2415-1653 N'8, March 2017, p. 3.
} 
The first emblematic figure of a simple, legal, and linear trajectory is represented in the emigrant who has come to the immigration land either as an ordinary familiar immigrant, a student, or a politically engaged refugee. This immigrant, a central figure in A. Sayad's $(1997$; 1999) sociology, is one whose journey is practically direct, for example Syria or Iraq towards Europe with a migratory project or an exile one. The inquiry shows that the journey is direct and by plane. The migrant does not face any risks and we have noted that amongst the 50 migrants, $30 \%$ of them, that is to say, 15 persons from the well-off middle class opted for this controlled trajectory without risks. Most of them arrived in Turkey and after a stay of between two and six months, obtained visas to go to Germany. This profile does not present a problem for Europe ${ }^{3}$.

As regards the sociology of exile, other than Smain Laacher (2005; 2007), Catherine Wihtol de Wenden (2005), and Nicholas P. De Genova (2002) have highlighted the trajectory of illegal immigrants through the concept of an illegal trajectory. The two terms, illegal trajectory, immediately evoke the unease and the problem: The qualitative "illegal" indicates a phenomenon whereby misfortune takes place and the expression illegal exile denotes in a greater way a problem or misfortune, it means the worst. The expression suggests the probable inability to become patron of the country where the migrant arrives, because the country will have trouble in maintaining its intact sovereign power over a foreigner who comes unexpectedly from abroad, the inverse of what laws and morals demand.

The illegal migrants of 2015 therefore make up a category apart, distinct from "ordinary" immigrants and refugees studied earlier (legal trajectory): They are individuals with specific traits that place them outside judicial conventions, defying the sovereignty of the State of Law but fleeing war-zones. According to the 1951 Geneva Convention, they have the right to set foot in a country which will not send them back to their country of departure. Seventy percent from our cross-section opted for this way ${ }^{4}$.

\section{Deaths in the Mediterranean Sea}

The iconic itinerary was the eastern, central, and western Mediterranean with the route taken by the majority of asylum seekers since the Arab Spring being Greece, Italy, and Spain in that order, as illustrated in the map below. The human outcome for those displacements by sea was very high and many lost their lives. Some of these adventurers from this new century received blows never ever heard off before. During four years 15,348 asylum seekers lost their lives, 10 persons every day. Because of the state holidays in Libya after the fall of Mouammar Kadhafi (1942-2011) in 2011 Central Mediterranean was the most dangerous.

Another worrying figure challenges us: Since 2000, according to sources we can estimate the number of deaths at being between 23,000 and 29,000, most of them taking place in the Mediterranean Sea, turning this sea into the migrants' cemetery $(2015$, p. 20).

\footnotetext{
${ }^{3}$ Interview in Paris Sunday October 25th 2015.

${ }^{4}$ Interview in Paris Sunday November 2nd 2015.
} 


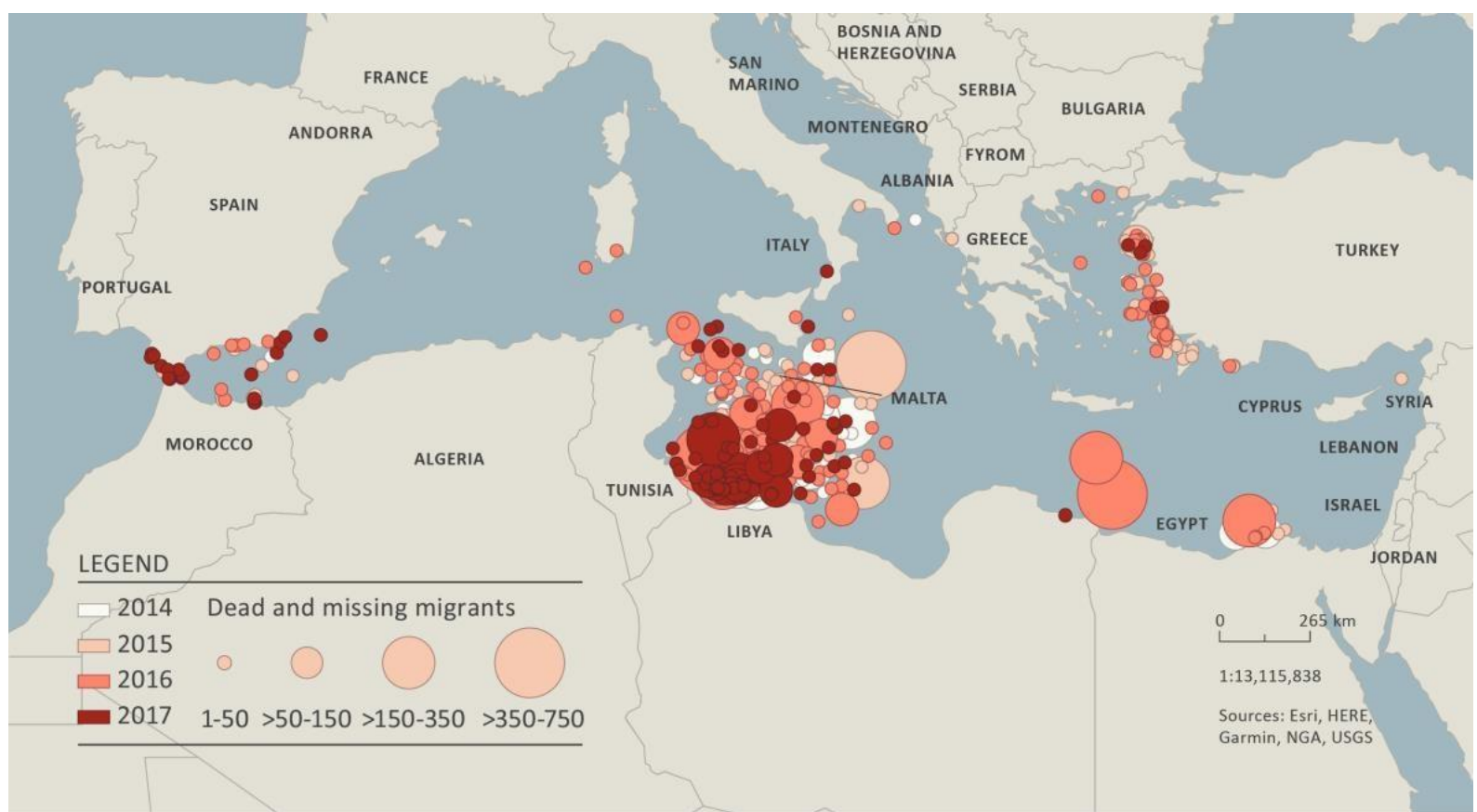

Figure 2. Deaths and the disappearance of migrants recorded in the Mediterranean ${ }^{5}$.

Table 1

Table Showing Deaths in the Mediterranean Between 2014 and $2018^{6}$

\begin{tabular}{lllll}
\hline Year & Central Mediterranean & Eastern Mediterranean & Western Mediterranean & Total \\
\hline 2014 & 3,165 & 59 & 59 & 3,283 \\
2015 & 2,877 & 804 & 102 & 3,783 \\
2016 & 4,581 & 434 & 128 & 5,143 \\
2017 & 2,853 & 62 & 224 & 3,139 \\
Total & 13,476 & 1,359 & 513 & 15,348 \\
\hline
\end{tabular}

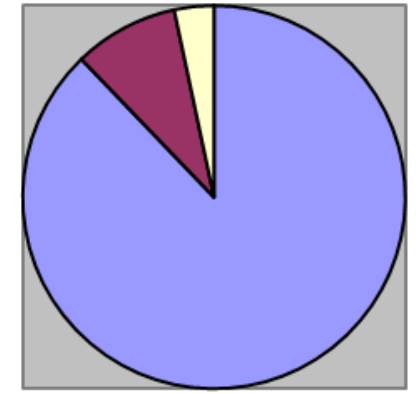

\begin{tabular}{l} 
पMéditerranée \\
Centrale \\
$\square$ Méditerranée \\
Orientale \\
$\begin{array}{c}\text { Méditerranée } \\
\text { Occidentale }\end{array}$ \\
\hline
\end{tabular}

Figure 3. Comparison of deaths in the three Mediterranean itineraries.

In order to understand better the danger of displacement, let us study the interview with Hamid, of Afghan origin, born in 1997 in Helmand in a family of seven children ${ }^{7}$. In 2015, Hamid first went into exile towards

\footnotetext{
5 Source: IOM's Missing Migrants Project, 2017. The boundaries and names shown and the designations used on this map do not imply official endorsement or acceptance by IOM. FYROM stands for the Former Yugoslav Republic of Macedonia.

6 See on International Organization of Migration web site: https://missingmigrants.iom.int/ (Consulted 20th March 2018).

7 Interview in Paris Thursday February 8th 2018.
} 
Iran. There, he took a smuggler who accompanied him along the Bazargan border to arrive in the border town of Van in Turkey. For one month there he had a tough time trying to find a smuggler for Greece. Thanks to help from his cousin in Tehran, he quickly met another smuggler who accompanied him from Ankara to a small town in Greece.

\footnotetext{
"There were already 45 of us, the smuggler wanted to board some more people in the inflatable boat, the amateur boat driver protested and threatened to immediately get down, consequently making the smuggler give in. We arrived safe and sound on a Greek island where we were well received by the Greek border guards and the representative of the High Commissioner of Refugees (HCR). The next day the HCR helped us to be free in Greece in order to continue our journey overland towards Germany crossing Macedonia and Hungary. We no longer needed smugglers. Large swamps of women, men, and children carrying the few belongings they could, made their way along the route. It was surreal. The scene resembled what you see in films only this time it was real. Sometimes I was in a group of about 100 people and sometimes 50 or even 200. After walking for about 14 days we arrived in Vienna in Austria. From there we went to Switzerland. Switzerland is an anti-Muslim country and in our hotel in one room there were three Christian Eritreans and they got a positive answer but one who was Muslim had his application rejected. I stayed two years. I had had enough. I had a friend in Paris and thanks to his help I came to France. I reapplied for asylum. It is a risk because if my fingerprints are disclosed, according to the Dublin Convention, France will deport me to the Swiss border" ${ }^{\prime 8}$.
}

Hamid's nightmare and the large number who died, make us think about the human question revealed in the philosophical tradition concerning the right to visit defended by philosophers ever since the Age of Enlightenment. Is Europe in the process of abandoning its values?

Let us have a look at Kant.

\section{The Right to Visit in the Philosophical European Tradition}

The 18th century, the Age of Enlightenment, following the discovery of America and the presence of the English in this new world, violent encounters ... certain concepts gained ground in order to better broach the foreigner and his rights.

Emmanuel Kant (1724-1804) was interested in the foreigner and his rights. In his final paper towards perpetual peace, the philosopher affirmed that "people's rights must be founded on a federalism of free nations" (Kant, 2006, p. 90). Emmanuel Kant goes deeper into the idea of universal peace by orienting himself towards the rights of the individual and proposing the right to visit which has been partially taken up by science researchers and at the same time falling by the wayside in relations between states.

There are seven pillars concerning the right to visit and in this article we are giving four of them.

(1) It is not a question of philanthropy (with a strong human approach) but the right for foreigners, a sort of hospitality, as soon as they have set foot in the country, and as a result they cannot be treated as enemies.

It is about the right to enter into a sovereign country.

(2) However if foreigners want to be accepted as citizens for a limited length of time, a particular treaty recognizing their rights needs to be passed.

It is the right to reside.

(3) Given that we live on a spherical earth "jointly owned by all men" and which cannot stretch to the infinite, the right to visit becomes ontological. Therefore, according to Kant, men "have to bear with each other in the end and the person who arrived first has no right to occupy a place other than anybody else" (Kant, 2006).

\footnotetext{
${ }^{8}$ Interview in Paris Thursday February 8th 2018.
} 
It is the right to fraternize on earth.

(4) Kant then suggested a cosmopolitan constitution based on "distant parts of the world being able to enter into mutual relations peacefully, relations which can in the end become public and legal and hence finally bring the human gender closer".

It is the right to be a citizen of the world.

We have to specify that the German philosopher brought out in September 1795 his petit manifest Vers la paix perpétuelle almost six months after a peace treaty between Prussia and revolutionary France and in which the implementation of universal peace confirmed the recognition of the right to hospitality for any person whose life was at risk in his home country. It categorically refused to envisage hospitality as being philanthropic or moral but a universal right for a temporary stay by accepting the right of the sovereignty of the state to grant an asylum seeker the right for permanent residence. Has this hospitality come to an end? Why has the Mediterranean become a dangerous border full of risks?

According to Evelyne Ritaine (2015), to put into perspective this European border genealogy of the Mediterranean, we have to remember that the opening up of an area that gave free movement to Europeans, Schengen, "was accompanied by a policy for controlling the outside border of the European Union: This was built on the paradigm of the management of "risks" established prior to the Schengen agreement by exchanges between professional security bodies. This paradigm, as well as the resistance of State members regarding the communitarization of migratory policies, prevented, through multiple crisis, incomplete indecisiveness and negotiations and the beginning of a real common policy on immigration and asylum. This absence is at the very root of the migration drama: in fact the autonomy of the migratory decision, the ability for migrants to react, imposing themselves on this border like on all the others. As soon as the Southern European states, after their accession to the Schengen Agreement, introduced compulsory visas for nationals from many foreign countries attempted to cross borders irregularly began, it brought the first dead. Those first missing were recorded in the Strait of Gibraltar at the beginning of the nineties, in the Strait of Otranto and in the Strait of Sicily as from 1993, around the Aegean Islands and the area around Evros in the middle of the nineties.

The continued reinforcement of controls and the resilience to migrate of populations from outside converged and made the Mediterranean a space of violence. Before the Schengen Agreement was implemented, the southern states more or less allowed the nationals from neighbouring countries to come and go according to seasonal activities and underground economy, or because it was only a question of transit migration on the way towards other European countries. Very quickly it became clear that in spite of difficulties to obtain visas, the populations concerned did not abandon crossing (Ritaine, 2015, p. 11).

The Mediterranean area is a lot more complex than the other highly controlled sea border, that of Australia. However, Australia by creating a camp on an island situated outside its country was able to dissuade the fluxes away from it. People therefore prefer to take the Mediterranean Sea and it is why the Mediterranean is progressively becoming more and more difficult to penetrate. The deployed military and police forces use technologies for controlling that are increasingly more innovative. The migratory pressure in the Balkans triggered off the erection of new barricades between Hungary and Serbia and Hungary and Croatia; finally, Austria has announced the building of a barrier at its border with Slovenia, laden with meaning, because it was the first to be situated within the Schengen area (Ritaine, 2015, p. 16). 


\section{Schengen Agreement and the Safeguarding of the Mediterranean}

Spain, in 1998, by introducing $\operatorname{SIVE}^{9}$ (System of External Vigilance), "a technological iron curtain," was the first country to initiate supervision from a distance and detection before the border. This system was taken up by the Mediterranean area following the creation of the European agency Frontex in 2004 and Eurosur in 2011. Military operations were added to these institutions of supervision. Since September 2001, NATO has launched as part of its dialogue on the Mediterranean, the operation Active Endeavour, to supervise the cooperation of the Mediterranean with bordering countries and the European and international agencies involved (Ritaine, 2015, p. 17).

The first hypothesis in search of the origin of the migratory crisis has been put forward by an important number of researchers including Evelyne Ritaine, who criticised the Schengen Agreement and the safeguarding of the Mediterranean.

The present "refugee crisis" at Europe's doors, is in this respect only the culmination of a political anomie which has lasted since the implementation of the Schengen Agreement. Reluctant, as from 2013 with the great loss at sea of migrants in the Mediterranean, the cooperation agreements between control norms and rescue norms (reticence illustrated by the Italian operation Mare Nostrum which fluctuated between two principles) as well as the fact that the States and the communitarian bodies continued to treat the arrivals of migrants in Europe as many successive emergencies and not as a structural fact calling on a strong policy (Ritaine, 2015, pp. 17-18).

Militarism generated zones of exception, camps "alienated for foreigners" official and unofficial, on both sides of the Mediterranean, because of the cooperation agreements on migratory policies passed with the transit countries. These camps are as much a part of the border; they form "exile corridors" (Agier, 2011). These structures (transit centres, detention centres, waiting zones, camps of foreigners more or less official) are intended to slow down the crossings, select those people who can finally enter, expulse the unwanted, and at the same time send a warning to the candidates who leave. The asylum seekers are in "spatial wandering of no location in no location"; they also live temporary vagrancy, a temporary status in a temporary status; they live in spaces of uncertain rights and run the risk of remaining blocked (Ritaine, 2015, pp. 18-19).

Consequently, Europe, first migratory destination in the world since the Arab Spring in 2011, is encircled by conflicts which are translated by the arrival on its soil of mixed fluxes because of the most important lines of world division, "at the same time demographic, economic, political, social and cultural" (Wihtol de Wenden, 2015). The aggravation of economic inequalities on a global scale, the arc of conflicts enclosing the Mediterranean - from North Africa to the Middle East and Sub-Saharan Africa-have then amplified the migratory movements towards Europe, meaning human loss. The areas are easily penetrable and have hence become more and more difficult to control; their progressive screening has led to discovering new illegal routes, increasingly dangerous for migrants, in a permanent process of diversion: There is therefore on developed world borders, a form of perpetual escalation maintained by the reinforcement of security (Andreas, 2000, p. 93).

Furthermore, contrary to popular belief, the geographical distribution of Syrians in three countries shows that the majority of migrants were crammed into three countries: Turkey (2,500,000 persons), Lebanon $(1,500,000)$, and Jordan $(800,000)^{10}$.

\footnotetext{
9 Sistema Integrado de Vigilencia Exterior.

http://www.unhcr.org/fr/news/stories/2017/6/5943f3eca/nombre-personnes-deplacees-atteint-haut-niveau-decennies.html, consulted February 10th 2018.
} 
Should we criticise the European Union for its lack of effort? An exceptional human answer faced with a painful economic climate was probably expected from Europe because of its fidelity to the values that founded it since the Second World War in order to reduce its fear of the other. But it was not the case. Following a pre-agreement between Turkey and Germany on March 7th 2016 ${ }^{11}$, the European Union decided on March 18th 2016, in Brussels to send back the migrants to Turkey: the principal of "one against the other". From a strictly mathematical point of view it rang fair, equitable ${ }^{12}$. But the decision remains problematic: It reinforces secular prejudices as long as we pretend that it is in the name of science and "academic neutrality" that we legitimize a journalistic approach to migration which implies that "migration is detrimental and a problem"13. Yet, migration is part of a societal transformation of the world as Zygmunt Bauman (1998) showed us in his book on the human cost of globalisation. Let us come back to the idea of Kant's citizen of the world and show how the modern state controls human displacements by borders, camps, visas, passports, generating undocumented workers, asylum seekers, and stateless persons. According to the sociologist, in an era of globalisation, "a global system of institutions and a democratic controlling of fluxes, matched with rules and ethical principles can be applied to all" (Wihtol de Wenden, 2013, p. 13).

So let us look at the migratory question with franchise. Was it necessary to bring in the 4,800,000 migrants distributed over the three countries mentioned?

All of current literature on social sciences supports a positive answer to this question. Michel Agier using an approach about "the anthropology of borders, mobility and migration" which he associates with human globalization and a new human condition suggested a new understanding between "Us" (the western states) people who are established, and "Them", exiles. It is this encounter between people who move about in Africa, the Middle-East and Southern Europe, and the French and European fears in recent days regarding the "migratory crisis" which has led him to take up these questions. Is there something else other than futile outrage? How do those established see the outsiders? What has relation been established between both of them (Agier, 2016. p. 10)?

The anthropologist by suggesting the expanding of spatial and temporary borders, an anticipatory global culture of borders, advocates for a solution towards broader and universal cosmopolitism. He considered that we have to "democratize the border" by understanding the example of Babel if we want to strengthen the scope and the real political meaning of democracy itself, and so is in keeping with Etienne Balibar who has been defending the democratization of the border for more than twenty years (Agier, 2016, p. 51).

Likewise, Catherine Wihtol de Wenden, in the Right to Emigrate, highlighted the legitimacy of fleeing a poor badly-governed country for the person born there. She takes up Aristide Zolberg's expression to say that it is legitimate to have access to a "suitable passport" to be able to move around, that is to say not to be subjected to getting a visa whatever the country one wants to go to (Wihtol de Wenden, 2013, p. 49).

Although these suggestions have a human dimension that is compatible with the values of the old continent, we believe that they collide with migratory policies in Europe which have abandoned the right to visit as seen by Kant, shown above. Consequently, it is necessary to reconsider some methodological and epistemological aspects and get away with some wrongly perceived concepts from before the year 2000 .

\footnotetext{
11 https://www.monde-diplomatique.fr/2017/01/KUNDNANI/56972, consulted February 8th 2018.

${ }^{12}$ https://www.la-croix.com/Monde/Europe/L-accord-entre-Union-europeenne-Turquie-adopte-2016-03-18-1200747723, February 15 th 2018

13 CASTLES Stephen, Conference on "Theories of Migration and Social Change”, St Anne's College, Woodstock Road, Oxford, Tuesday 1st-Thursday 3rd July 2008.
} 


\section{Conclusion}

The migratory crisis of 2015, which has resurfaced ever since the fall of the Berlin Wall, intensified by the intervention of the United States in Iraq and Afghanistan and which bounced back following the Arab Spring of 2012, would be the consequence of colonial relations and authoritarian modernized regimes produced by decolonization just after the Second World War. These authoritarian regimes from the Middle-East, North Africa, and Africa, built by and socialized largely by western powers throughout the Cold War, have generated on the one hand a model of partial economic development without the political liberalism of the public space and available labor force needed to relaunch Europe's economy destroyed after the War on the other hand.

In the sixties, these authoritarian regimes, such as that of Moubarak in Egypt, Benali in Tunisia, and Bachir in Syria, whipped up illusions about a rupture with colonialism. However, we can retrospectively now say that they were only throwing sand in the public's eye. These regimes embody four characteristics: economic planning by implementing agrarian reforms, pushing aside the liberalisation of the political sphere and the democratisation of the State with a unique party, the artificial separation between the State and religion pursuing a repressive policy on Islamic movements, and finally a repressive army with a secret political police to suppress the opposition (Arendt, 2005, pp. 30-100).

Yet, the Arab Spring has shown that we are dealing with unfinished post-colonialism (Saïd, 1997, pp. 20-60), something that we will soon come back to in another article to propose another solution.

As long as this authoritarian structure exists, it seems to me that migration reproduces itself sociologically speaking, and, in the short term, there are no efficient solutions to contain the flow.

\section{References}

Agier, M. (2011). Le couloir des exilés. Etre étranger dans un monde commun (The exiles' corridor. To be a foreigner in a common world). Paris, Editions du Croquant

Agier, M. (2016). Les migrants et nous, Comprendre Babel (Migrants and us, Understanding Babel). Paris, CNRS Editions.

Arendt, H. (2005). Les origines du totalitarisme, Le système totalitaire (The origins of totalitarianism, the totalitarian system).

Paris, Seuil.

Bauman, Z. (1998). Globalization: The Human Consequences. Londres, Polity Press and Blackwell Publishers Ltd.

Bauman, Z. (1999). Le coût humain de la mondialisation (The human cost of globalisation). Paris, Hachette Littérature.

Bigo, D. (1998). L'immigration au carrefour des sécurités (Immigration at the crossroads of security). Revue Européenne des

Migrations internationales (European review on International Migration), 14/1.

Brambilla, C. (2015). Exploring the Critical Potential of the Borderscapes Concept. Geopolitics, 20/1.

De Genova, N. P. (2002). Migrant "illegality" and deportability in everyday life. Annual Review of Anthropology, 31, Oct.

Kant, E. (2006). Vers la paix perpétuelle (Towards everlasting peace) (1795). Paris, Flammarion.

Laacher, S. (2005). Éléments pour une sociologie de l'exil (Elements for a sociology on exile). Politix, $\mathrm{N}^{\circ} 69$, Paris.

Laacher, S. (2007). Le peuple des clandestins (An illegal people). Paris, Calment-Levy.

Le Blanc, G., \& Brugère, F. (2017). La fin de l'hospitalité, Lampedusa, Lesbos, Calais ...jusqu'où irons-nous? (The end of hospitality, Lampedusa, Lesbos, Calais... just how far will we go?). Paris, Flammarion.

Miles, R., \& Thranhardt, D. (1995). Migration and European Integration, the Dynamics of Inclusion and Exclusion. London, Pinter.

Ritaine, E. (2015). Blessures de frontière en Méditerranée (Border injuries on the Mediterranean). Cultures \& Conflits, N99/100, Automne/hiver, Paris.

Saïd, E. (1997). Orientalisme (Orientalism). Paris, Seuil.

Sayad, A. (1997). L'immigration ou les paradoxes de l'altérité (Immigration or the paradox of otherness). Paris, De Boeck.

Sayad, A. (1999). La double absence (Double absence). Paris, Seuil.

Strauss, A. (1992). La trame de la négociation: sociologie qualitative et interactionnisme, in Bazanger (The negotiation plot: Qualitative socialism and interactionism). Paris, L'Harmattan. 
Vahabi, N. (2012). Atlas de la diaspora iranienne (Atlas of the Iranian diaspora). Paris, Karthala.

Wihtol De Wenden, C. (2005). Atlas des migrations dans le monde, Réfugiés ou migrants volontaires (Atlas of world migration, Refugees or voluntary migrants). Paris, Autrement.

Wihtol de Wenden, C. (2013). Le droit d'émigrer (The right to emigrate). CNRS Editions, Paris. 